\title{
An investigation into the smoldering combustion of paper
}

\author{
A. Tinaburri ${ }^{1,2}$, F. A. Ponziani ${ }^{1,2} \&$ V. Ricci ${ }^{1}$ \\ ${ }^{1}$ Central Direction for Prevention and Technical Safety, \\ Department of Firefighters, Ministry of the Interior, Italy \\ ${ }^{2}$ Department of Industrial Engineering, \\ Rome "Tor Vergata" University, Italy
}

\begin{abstract}
Following some fire investigation activities on the smoldering phase of paper items in a stack configuration, a campaign of tests was conducted to examine the particular dynamics of this type of combustion. The smoldering phase of stacks made up by various paper elements was investigated, using heptane poured on the top of the stack as the ignition source. The following parameters were varied: size and grammage of the paper sheets; height of the paper stack. Several thermocouples and a scale were used to log data during each test whose duration was on a typical timescale of a day. Among the outcome, two issues of paramount importance for the smoldering phase under analysis were highlighted: the identification of a constant mass loss rate phase and, provided the ignition source is of sufficient strength, the total involvement of the paper stack if sufficient time is allowed for the smoldering combustion to proceed. A regression model based on the test results was then developed that could take into account the behavior of the smoldering combustion representative of the different paper format under investigation. A metric useful for reconstruction of smoldering of a paper stack is thus derived.
\end{abstract}

Keywords: smoldering, mass loss, paper stack, combustion, flaming.

\section{Introduction}

The starting point for this research was an investigation into an arson fire of a number of stacks of paper or binders. Among the several questions raised, one was outstanding and challenging. After a flaming combustion process is 
activated by the pouring of relatively small quantities of an accelerant liquid, will the combustible package be able to self-sustain the combustion process, and if so, in which form (flaming vs. smoldering), to which extent (partial vs. total involvement) and how long?

Recognizing the limitations of the current software in modeling flaming to smoldering transition and the following smoldering combustion (if any), laboratory tests were performed in a confined space to obtain basic data on the critical parameters representing the smoldering behavior of stacks of paper. The ignition source was obtained by pouring a small quantity of liquid accelerant (heptane, $35 \div 200 \mathrm{ml}$, typically $70 \mathrm{ml}$ ) mainly on top of the stack. This technique is representative of all cases in which the combustion of the stack is initiated by a transient heat flux applied to the top layers.

\section{The experimental campaign}

Several tests were performed to study the combustion behavior of paper sheets differing for sizes (from $10.5 \times 42 \mathrm{~cm}$ to $40 \times 56 \mathrm{~cm}$ ), grammage (from 40 to $200 \mathrm{~g} / \mathrm{m}^{2}$ ) of the sheet and initial mass (height) of the stack (from 3836 to 9885 g). For each test performed, the following parameters were recorded: flaming combustion duration and possible transition to smoldering, mass loss rate along all the combustion process, temperature profile in ten points inside the stack. The tests have been performed in a confined space having a total volume $\approx 766 \mathrm{~m}^{3}$, large enough to supply the air required by the combustion reactions. Single paper sheets of different grammage and size have been arranged in a stack configuration. The paper stack weight loss as a function of time has been measured with a Sartorius scale, type BP34000-P, connected to a computer station for data logging. Ten thermocouples (type K) have been provided to record the temperature inside the burning material with a data logger (Datataker, model DT 500), with a sampling rate of $30 \mathrm{~s}$. Refer to Figure 1 for the thermocouples location details: the monitoring points were selected in order to minimize the disturbance caused by the initial flaming phase and by the shape changes caused by the combustion reactions (for instance small material collapse during smoldering).

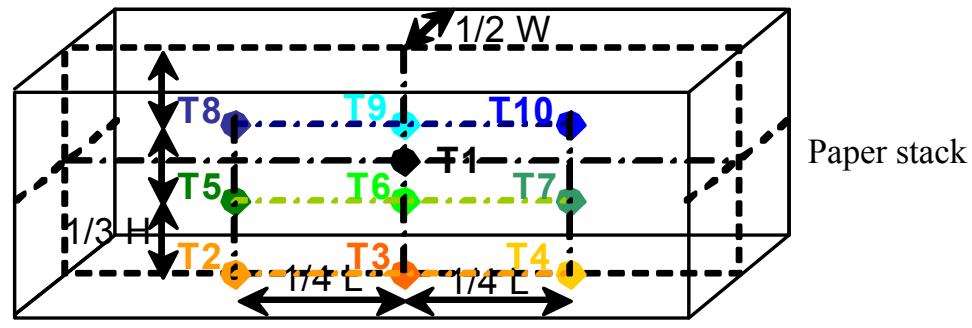

Figure 1: Thermocouples arrangement. 
Table 1 shows the summary of the tests performed, where the smoldering mechanism has been activated after the initial flaming phase.

Table 1: $\quad$ Summary of smoldering test results.

\begin{tabular}{|c|c|c|c|c|c|c|}
\hline \multirow{3}{*}{$\begin{array}{l}\text { Test } \\
\text { no. }\end{array}$} & \multirow[t]{3}{*}{ Paper sheet type } & \multirow{3}{*}{$\begin{array}{l}\text { Paper } \\
\text { initial } \\
\text { mass } \\
(\mathrm{g})\end{array}$} & \multicolumn{4}{|c|}{ Smoldering combustion } \\
\hline & & & \multicolumn{2}{|c|}{$\begin{array}{l}1^{\text {st }} \text { phase: Linear } \\
\text { mass loss }\end{array}$} & \multicolumn{2}{|c|}{$\begin{array}{c}2^{\text {nd }} \text { phase: Quadratic } \\
\text { mass loss }\end{array}$} \\
\hline & & & $\begin{array}{l}\text { Duration } \\
\text { (min) }\end{array}$ & $\begin{array}{c}\text { Mass loss } \\
\text { (\% initial } \\
\text { mass })\end{array}$ & $\begin{array}{l}\text { Duration } \\
\text { (min) }\end{array}$ & $\begin{array}{c}\text { Mass loss } \\
(\% \text { initial } \\
\text { mass })\end{array}$ \\
\hline 1 & $\begin{array}{l}\text { Glossy paper (bindakote) } \\
\text { Dimensions (LxW): } 50 \text { × } 35 \mathrm{~cm} \\
\text { Paper grammage: } 200 \mathrm{~g} / \mathrm{m}^{2} \\
\text { Stack height }(\mathrm{H}): 7 \mathrm{~cm}\end{array}$ & 9094 & 855 & 68.5 & 1333 & 12.5 \\
\hline 2 & As test n. 1 & 9105 & 833 & 67.5 & 1326 & 13.3 \\
\hline 3 & $\begin{array}{c}\text { As test n. } 1 \\
\text { with a reduced stack height: } 3.5 \mathrm{~cm}\end{array}$ & 4313 & 245 & 48.8 & 301 & 15.8 \\
\hline 4 & $\begin{array}{l}\text { Cardboard } \\
\text { Dimensions (LxW): } 42 \times 10.5 \mathrm{~cm} \\
\text { Paper grammage: } 200 \mathrm{~g} / \mathrm{m}^{2} \\
\text { Stack height (H): } 10.5 \mathrm{~cm}\end{array}$ & 3836 & 551 & 67.9 & 325 & 5.8 \\
\hline 5 & \begin{tabular}{l}
\multicolumn{1}{c}{ A3 paper } \\
Dimensions $(\mathrm{LxW}): 42 \times 29.7 \mathrm{~cm}$ \\
Paper grammage: $80 \mathrm{~g} / \mathrm{m}^{2}$ \\
Stack height $(\mathrm{H}): 9.8 \mathrm{~cm}$
\end{tabular} & 9885 & & & te 1 & \\
\hline 6 & \begin{tabular}{l}
\multicolumn{1}{c}{ Newspaper } \\
Dimensions $(\mathrm{LxW}): 35$ x $25 \mathrm{~cm}$ \\
Paper grammage: $40 \mathrm{~g} / \mathrm{m}^{2}$ \\
Stack height $(\mathrm{H}): \sim 21 \mathrm{~cm}$ \\
\end{tabular} & 8097 & 1334 & 49.7 & 1490 & 36.9 \\
\hline 7 & \begin{tabular}{|c|c|}
\multicolumn{1}{c}{ Newspaper } \\
2 adjacent stacks \\
Dimensions $(\mathrm{LxW}):(2 \times 22) \times 31 \mathrm{~cm}$ \\
Paper grammage: $40 \mathrm{~g} / \mathrm{m}^{2}$ \\
Stack height $(\mathrm{H}): \sim 13.5 \mathrm{~cm}$
\end{tabular} & 8145 & 2107 & 53.7 & 1021 & 35.9 \\
\hline 8 & $\begin{array}{l}\text { Newspaper } \\
\text { Dimensions }(\mathrm{LxW}): 30 \text { x } 20.5 \mathrm{~cm} \\
\text { Paper grammage: } 40 \mathrm{~g} / \mathrm{m}^{2} \\
\text { Stack height }(\mathrm{H}): \sim 16 \mathrm{~cm} \\
\end{array}$ & 4460 & 1232 & 49.0 & 1250 & 34.2 \\
\hline 9 & \begin{tabular}{l}
\multicolumn{1}{c}{ Newspaper } \\
Dimensions $(\mathrm{LxW}): 40$ x $29 \mathrm{~cm}$ \\
Paper grammage: $40 \mathrm{~g} / \mathrm{m}^{2}$ \\
Stack height $(\mathrm{H}): \sim 13 \mathrm{~cm}$
\end{tabular} & 6906 & 1222 & 53.5 & 1751 & 30.6 \\
\hline
\end{tabular}

Note 1: Test intentionally interrupted after 47 hours @ 72\% paper mass loss.

Even if it is not dealt with in this paper, it may be useful to report that the initial flaming phase had a duration in the order of 15 minutes and an overall mass loss in the range of $1 \div 5 \%$ referred to the initial paper mass. The accelerant quantity was selected to be the minimum required to initiate a smoldering phenomenon, if any, for each paper type and format. The fuel package shape changes assuming a complex $3 \mathrm{D}$ pattern, with an increase of the sample apparent 
height caused by the top stack sheets that are bended and turned by the flame attack leaving a typical black colored residue (Figure 2).

Test n. 1: Glossy paper (bindakote)

Size (LxW): $50 x 35 \mathrm{~cm}$, paper grammage: $200 \mathrm{~g} / \mathrm{m}^{2}$, stack height $(\mathrm{H}): 7 \mathrm{~cm}$

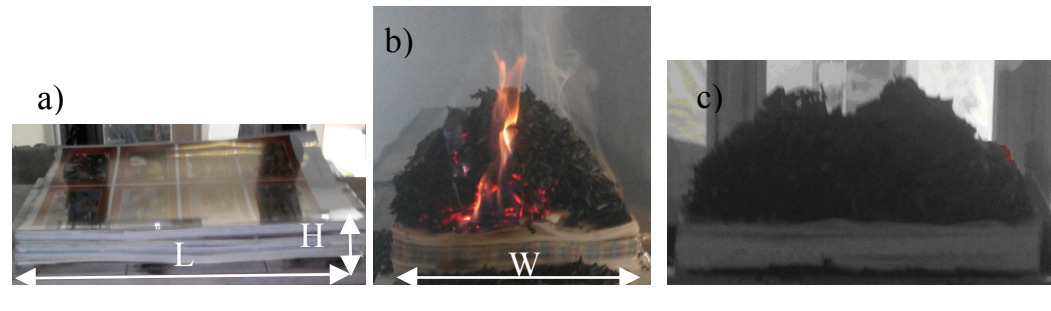

Test n. 6: Newspaper

Size (LxW): $35 \times 25 \mathrm{~cm}$, paper grammage: $40 \mathrm{~g} / \mathrm{m}^{2}$, stack height $(\mathrm{H}): \sim 21 \mathrm{~cm}$

a)
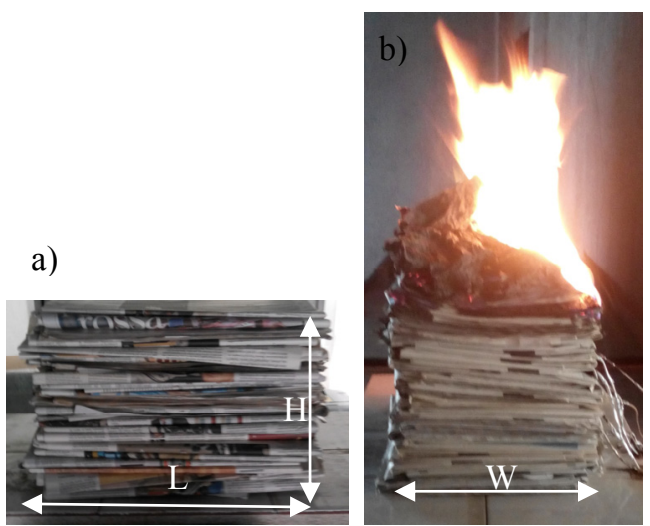

c)

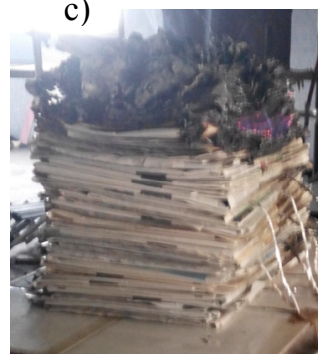

Test n. 9: Newspaper

Size (LxW): 40x29 cm, paper grammage: $40 \mathrm{~g} / \mathrm{m}^{2}$, stack height $(\mathrm{H}): \sim 13 \mathrm{~cm}$

a)

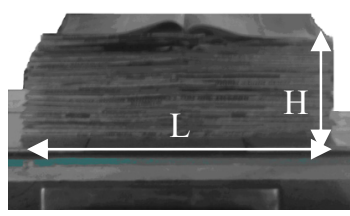

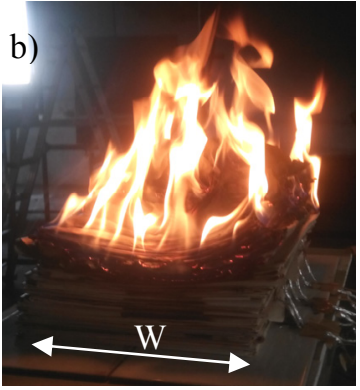

c)

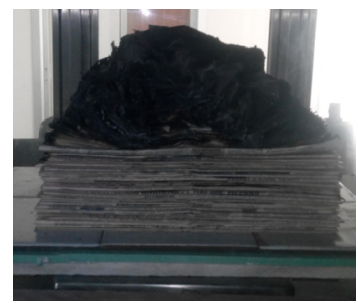

Figure 2: Material morphology during flaming phase till smoldering starts a) prior to ignition; b) during the flaming phase; c) flame out, the start of smoldering. 
After this initial stage, smoldering may or may not proceed depending on the fuel package configuration. It has been observed on that respect that the A3 format or the cardboard strips are more prone to sustain the combustion reactions till complete consumption, leaving mainly white unburned residue (ash) under the external black appearance left by the flaming phase (Figure 3 ).

Test n. 1: Glossy paper (bindakote)

Initial size (LxWxH): $50 \times 35 \times 7 \mathrm{~cm}$, paper grammage: $200 \mathrm{~g} / \mathrm{m}^{2}$

a) External (front view); b) Internal
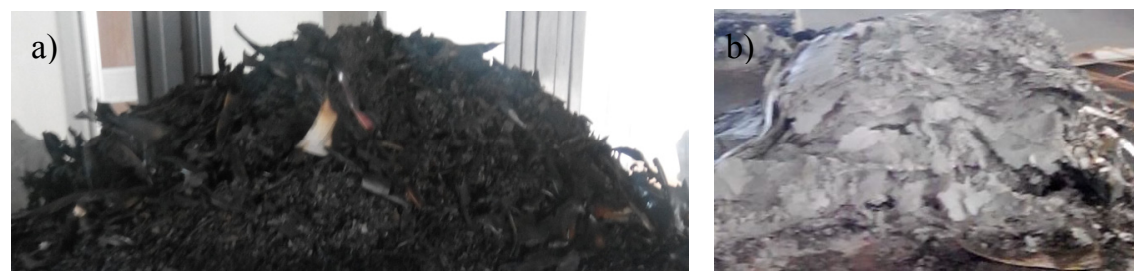

Test n. 4: Cardboard

Initial size (LxWxH): $42 \times 10.5 \times 10.5 \mathrm{~cm}$, paper grammage: $200 \mathrm{~g} / \mathrm{m}^{2}$

a) External (front view); b) Internal
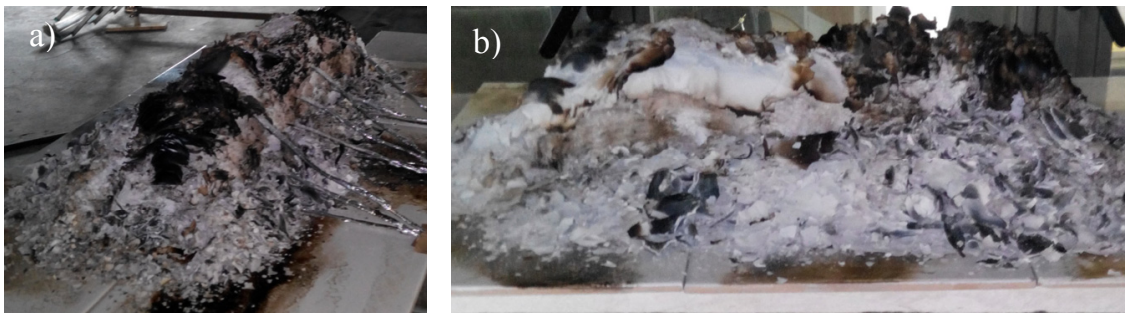

Figure 3: Final material morphology.

Newspapers activate a slower smoldering process influenced by the folding, that introduce anisotropy in the fuel package response to the flame attack. For the largest size (Test n. 9), it was necessary to repeat the test several times increasing the accelerant amount to the maximum ever used $(200 \mathrm{ml})$, partially $(25 \%)$ poured also in the first two top leaves, in order to observe the smoldering process to proceed to complete paper consumption. The following Figures 4 and 5 report the measured sample mass and temperature profiles (refer to Figure 1) for six of the tests performed. In order to facilitate the comparison, results are ordered in group of three on the basis of the sample initial mass and in each graph same time/temperature/mass scale is selected. These experiments demonstrated that the process is characterized by a first phase of constant rate of mass loss (linear decay of the sample mass) followed by a progressive decline of the rate of mass loss which is nearly linear (quadratic decay of the sample mass). Unburned residue (ash) is about $16 \%$ of the initial mass. The overall duration and mass loss during each of this two phases is summarized in Table 1 for all the tests. 
Test n. 3: Glossy paper $200 \mathrm{~g} / \mathrm{m}, \mathrm{LxW}: 50 x 35 \mathrm{~cm}, \mathrm{H}: 3.5 \mathrm{~cm}, \mathrm{M}=4313 \mathrm{~g}$

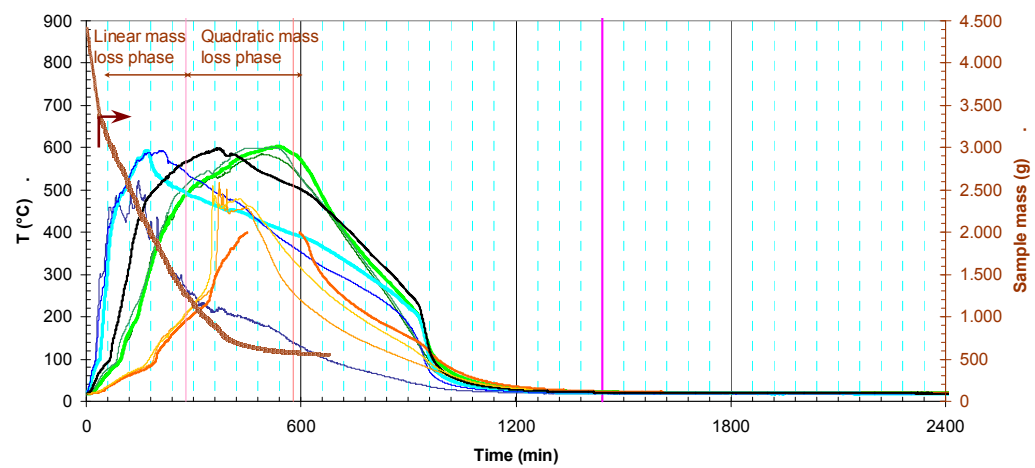

Test n. 4: Cardboard 200 g/m , LxW: $42 \times 10.5$ cm, H: $10.5 \mathrm{~cm}, \mathrm{M}=3836 \mathrm{~g}$

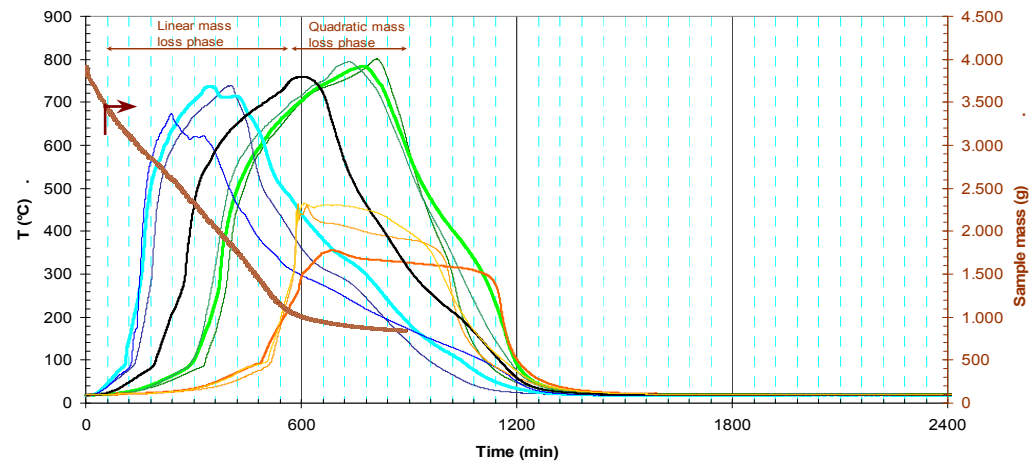

Test n. 8: Newspaper $40 \mathrm{~g} / \mathrm{m}, \mathrm{LxW}: 30 \times 20.5 \mathrm{~cm}, \mathrm{H} \sim 16 \mathrm{~cm}, \mathrm{M}=4460 \mathrm{~g}$

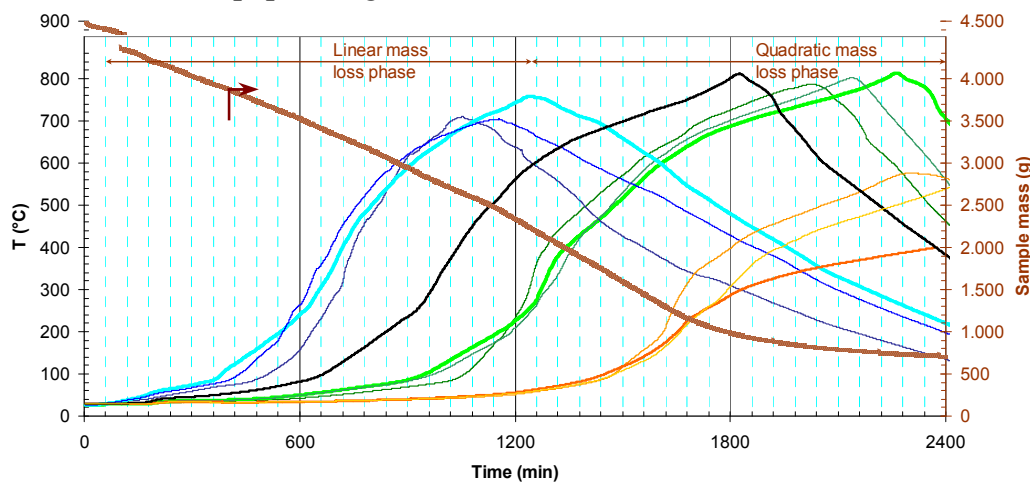

$-\mathrm{T} 8-\mathrm{T} 9-\mathrm{T} 10(2 / 3 \mathrm{H}),-\mathrm{T} 1(1 / 2 \mathrm{H}),-\mathrm{T} 5-\mathrm{T} 6-\mathrm{T} 7(1 / 3 \mathrm{H}),-\mathrm{T} 2-\mathrm{T} 3-\mathrm{T} 4$ (bottom)

Figure 4: Sample mass and thermocouples profiles. 
Test n. 9: Newspaper $40 \mathrm{~g} / \mathrm{m}^{2}$, LxW: 40x29 cm, H $13 \mathrm{~cm}, \mathrm{M}=6906 \mathrm{~g}$

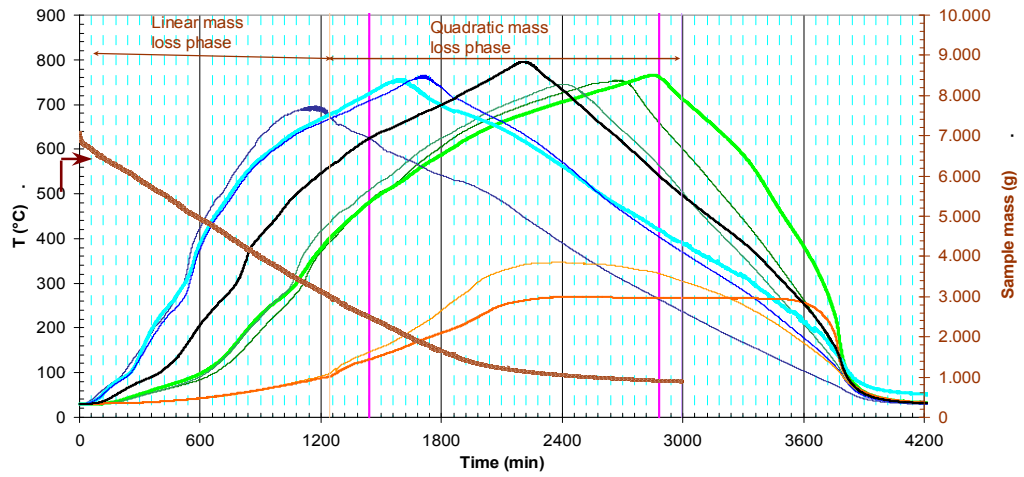

Test n. 6: Newspaper $40 \mathrm{~g} / \mathrm{m}^{2}$, LxW: 35x25 cm, H $21 \mathrm{~cm}, \mathrm{M}=8097 \mathrm{~g}$

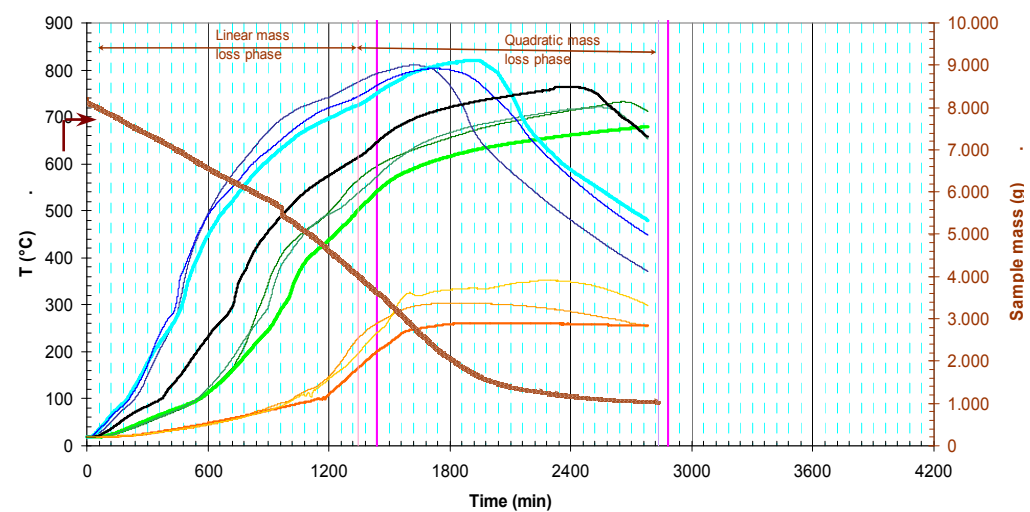

Test n. 5: A3 sheets $80 \mathrm{~g} / \mathrm{m}^{2}$, LxW: 42x29.7 cm, H: $9.8 \mathrm{~cm}, \mathrm{M}=9885 \mathrm{~g}$

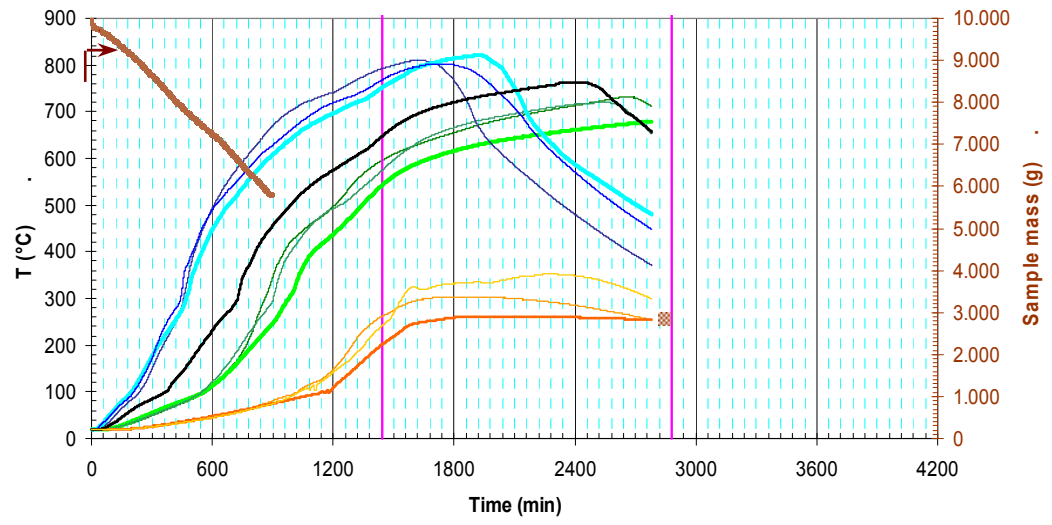

- T8 - T9 - T10 (2/3 H), - T1 (1/2H), - T5 - T6 - T7 (1/3H), - T2 - T3 - T4 (bottom)

Figure 5: Sample mass and thermocouples profiles. 
The temperature profiles within each sample reproduce the typical dynamics of the smoldering: a phase of penetration of the thermal wave with a temperature increase, resulting in the activation of the glowing combustion within the stack, followed by a cooling phase. Each group of three thermocouples located in the same horizontal plane shows a similar trend: at any given time in the growing phase the two external thermocouples record higher temperature than the central thermocouple, the reverse occurring in the decaying phase. The maximum temperatures recorded are in the order of $600-800^{\circ} \mathrm{C}$, as reported in the literature [1]. The peak temperature at the base level (TCs 2,3,4) is always well below the above mentioned maximum value, the spread being the lowest for the sample having the minimum initial height (Run n.3). These results confirmed a trend also observed in a previous campaign focused on the A4 format [2]. To link the measured physical data to the extent of the reaction volume inside the stack, Test n. 5 was interrupted after $\sim 47 \mathrm{~h}$ from the ignition, to unveil the interior appearance of the sample. As shown in Figure 6, after removing the surrounding external ash, it is possible to isolate a glowing core and to determine its dimensions and shape. The last two photos in the sequence show the detail of the core structure: several single sheet parts all involved in glowing reactions.
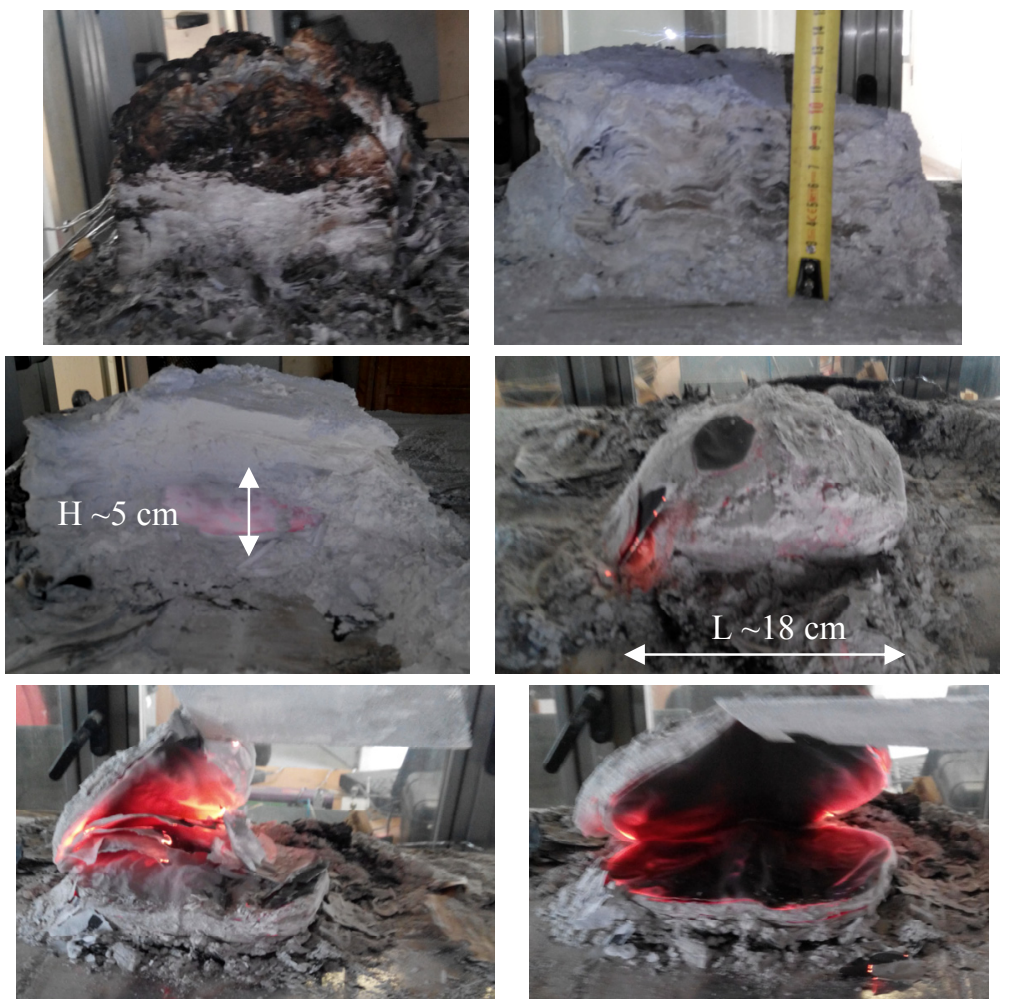

Figure 6: Test n. 5: Smoldering zone after $47 \mathrm{~h}$ from the ignition. (A3 sheets $80 \mathrm{~g} / \mathrm{m}^{2}$, LxWxH: 42x29.7x9.8 cm, M=9885 g.) 


\section{Analysis of the smoldering phenomenon of paper stack}

The smoldering combustion is a chemical reaction in heterogeneous phase, its study requiring knowledge of the phenomena of heat and mass transport in both the gas and solid phase. To initiate the reactions mechanisms, external energy is required to heat the solid fuel. The resulting increase in temperature of the solid phase starts, above a temperature characteristic of the material, the thermal degradation reactions until the balance between net heat generated by the oxidation reactions is sufficiently high to compensate the heat required for the propagation of the front of reaction to layers of adjacent material still "virgin" and the heat losses towards the outside. Factors such as ignition source geometry, fuel geometry, and the strong influence of buoyant flow on oxygen supply usually interact to assure that a smoldering reaction zone has significant gradients of temperature and species in two or three dimensions. In examining self-sustained smolder propagation and its response to oxygen supply conditions, dimensionality is important. For the configuration examined, when the top layer is ignited, the fuel package soon evolves into a new complex shape. Thermal diffusion and smoldering reactions cause a curvature of each individual paper element thus determining a change in shape and porosity of the fuel package that can enhance air penetration. On that respect, folding in newspapers introduces a further factor to consider: the presence of one or more spines obstacles air diffusion inside the stack, introduce an anisotropy also depending on their relative orientation. The result is a reaction zone that propagates downward from the top of the stack to the bottom. The air inflow is arriving mainly from the stack lateral sides (in a cross-flow pattern) under natural convection conditions, favored also by the curvature of the fuel element borders, while the hot gases produced move upward. At any given depth in the stack, the reaction front proceeds mainly from the external to the internal core. The result is a reaction volume that moves downward from the top of the layer to the bottom, involving multiple sheets in a reaction zone that is several centimeters thick. As the fuel package under analysis is highly permeable to air and of relatively small size, oxygen surrounds the fuel particles as they are heated by the advancing reaction zone: as a consequence the curvature of the surface delimitating this volume is relatively small compared to its dimensions.

Table 2 shows the summary of the least squares regression of the sample mass data. Discarding the initial flaming phase, smoldering data were fitted starting from a reference time of 60 minutes. The best fit is obtained by a linear function in time, followed by a $2^{\text {nd }}$ order polynomial modeling the decaying phase; the correlation coefficients show the degree of accuracy of the regression along the whole time line. The onset of a linear mass loss phase indicates that the self-sustained smoldering volume is in steady-state condition. The constancy of the mass loss rate implies that a constant reaction volume is established in the stack and travels downward at a constant velocity, and across it occurs the transition from unburned fuel to ash. A very simplified representation of the phenomenon is possible by a global energy balance around this smoldering 
Table 2: Smoldering data analysis.

\begin{tabular}{|c|c|c|c|c|c|c|c|c|c|c|}
\hline \multirow{3}{*}{$\begin{array}{l}\text { Test } \\
\text { no. }\end{array}$} & \multirow{3}{*}{$\begin{array}{l}\text { Paper sheet } \\
\text { type }\end{array}$} & \multirow{3}{*}{$\begin{array}{l}\text { Paper } \\
\text { initial } \\
\text { mass } \\
(\mathrm{g})\end{array}$} & \multicolumn{8}{|c|}{ Smoldering combustion } \\
\hline & & & \multicolumn{3}{|c|}{$\begin{array}{c}1^{\text {st }} \text { phase: Linear curve } \\
\mathrm{M}(\mathrm{t})=\mathrm{Mo}-\mathrm{k}_{\text {lin }} \mathrm{t} \\
60<\mathrm{t}<\mathrm{t}_{1, \operatorname{lin}}(\min )\end{array}$} & \multicolumn{5}{|c|}{$\begin{array}{c}2^{\text {nd }} \text { phase: Quadratic curve } \\
\mathrm{M}(\mathrm{t})=k_{\text {quad, }, 2} \mathrm{t}^{2}+k_{\text {quad, }, 1} \mathrm{t}+k_{\text {quad }} \\
\mathrm{t}_{1, \text { lin }}<\mathrm{t}<\mathrm{t}_{2, \text { quad }}(\min )\end{array}$} \\
\hline & & & $\begin{array}{l}\mathrm{t}_{1, \operatorname{lin}} \\
(\mathrm{min})\end{array}$ & \begin{tabular}{|c|} 
Constant \\
mass loss \\
rate $k_{\text {lin }}$ \\
$(\mathrm{g} / \mathrm{min})$
\end{tabular} & $\mathrm{r}^{2}$ & $\begin{array}{l}\mathrm{t}_{2, \text { quad }} \\
(\mathrm{min})\end{array}$ & \begin{tabular}{|l|}
$k_{\text {quad, }}$ \\
$\left(\mathrm{g} / \min ^{2}\right)$
\end{tabular} & $\begin{array}{l}k_{\text {quad, } 1} \\
(\mathrm{~g} / \mathrm{min})\end{array}$ & $\begin{array}{c}k_{\text {quad }} \\
(\mathrm{g})\end{array}$ & $\mathrm{r}^{2}$ \\
\hline 1 & $\begin{array}{l}\text { Glossy paper } \\
\text { LxW: } 50 \times 35 \mathrm{~cm} \\
\text { Gram.: } 200 \mathrm{~g} / \mathrm{m}^{2} \\
\mathrm{H}: 7 \mathrm{~cm}\end{array}$ & 9094 & 870 & 7.0223 & 0.997 & 2204 & 0.0009 & -3.4614 & 4528.2 & 0.992 \\
\hline 2 & As test n. 1 & 9105 & 845 & 6.7579 & 0.997 & 2170 & 0.0009 & -3.3625 & 4386.3 & 0.950 \\
\hline 3 & $\begin{array}{l}\text { As test } \mathrm{n} .1 \\
\text { but } \mathrm{H}=3.5 \mathrm{~cm}\end{array}$ & 4313 & 245 & 8.6308 & 0.997 & 578 & 0.0109 & -11.436 & 3279.2 & 0.994 \\
\hline 4 & $\begin{array}{l}\text { Cardboard } \\
\text { LxW: } 42 \times 10.5 \mathrm{~cm} \\
\text { Gram.: } 200 \mathrm{~g} / \mathrm{m}^{2} \\
\text { H: } 10.5 \mathrm{~cm}\end{array}$ & 3836 & 564 & 4.6467 & 0.999 & 889 & \begin{tabular}{|l|}
0.0019 \\
\end{tabular} & -3.3707 & $\mid 2347.7$ & 0.994 \\
\hline 5 & $\begin{array}{l}\text { A3 paper } \\
\text { LxW: } 42 \times 29.7 \mathrm{~cm} \\
\text { Gram.: } 80 \mathrm{~g} / \mathrm{m}^{2} \\
\text { H: } 9.8 \mathrm{~cm}\end{array}$ & 9885 & & 4.7166 & 0.999 & \multicolumn{5}{|c|}{ Test intentionally interrupted after 47 hours } \\
\hline 6 & $\begin{array}{l}\text { Newspaper } \\
\text { LxW: } 35 \times 25 \mathrm{~cm} \\
\text { Gram.: } 40 \mathrm{~g} / \mathrm{m}^{2} \\
\mathrm{H}: \sim 21 \mathrm{~cm}\end{array}$ & 8097 & 1344 & 2.9864 & 0.99 & 2834 & 0.0021 & -10.81 & 14684 & 0.991 \\
\hline 7 & $\begin{array}{l}\text { Newspaper } \\
2 \text { adjacent stacks } \\
\text { LxW: }(2 \times 22) \times 31 \mathrm{~cm} \\
\text { Gram.: } 40 \mathrm{~g} / \mathrm{m}^{2} \\
\text { H: } \sim 13.5 \mathrm{~cm}\end{array}$ & 8145 & 2122 & 2.0275 & 0.996 & 3142 & 0.0041 & -24.68 & 37767 & 0.988 \\
\hline 8 & $\begin{array}{l}\text { Newspaper } \\
\text { LxW: } 30 \times 20.5 \mathrm{~cm} \\
\text { Gram.: } 40 \mathrm{~g} / \mathrm{m}^{2} \\
\mathrm{H}: \sim 16 \mathrm{~cm}\end{array}$ & 4460 & 1245 & 1.8385 & 0.998 & 2495 & 0.0015 & -6.6503 & 8254 & 0.994 \\
\hline 9 & $\begin{array}{l}\text { Newspaper } \\
\text { LxW: } 40 x 29 \mathrm{~cm} \\
\text { Gram.: } 40 \mathrm{~g} / \mathrm{m}^{2} \\
\mathrm{H}: \sim 13 \mathrm{~cm}\end{array}$ & 6906 & 1242 & 3.1246 & 0.999 & 2993 & 0.0010 & -5.3562 & 8111 & 0.994 \\
\hline
\end{tabular}

volume [3]. The velocity of propagation is determined by the balance between the heat released in the volume by the smoldering reactions and the energy required to heat the "virgin" solid fuel and the air at the higher temperature of the front of smoldering, taking into account heat losses to the environment. The quadratic mass loss phase corresponds to the transition that occurs when the smoldering front approaches the bottom of the stack: the fuel depletion causes a linear shrinkage in time of the reaction volume, which is still several centimeters thick as shown in Figure 6. 
A nominal downward smoldering velocity $u_{\text {sml }}$ can be determined by the relation:

$$
u_{s m l}=\frac{(\Delta \mathrm{m} / \Delta \mathrm{t})}{\rho_{s}(1-\phi) A_{c}}=\frac{(\Delta \mathrm{m} / \Delta \mathrm{t})}{(\mathrm{M} / \mathrm{H})}
$$

where $\mathrm{M}, \mathrm{H}$ and $\mathrm{A}_{\mathrm{c}}$ are, respectively, the sample initial mass and height and cross section, $\rho_{\mathrm{s}}$. is the density of the paper, $\phi$ is the porosity of the fuel package and $(\Delta \mathrm{m} / \Delta \mathrm{t})$ is the mass loss rate. For the linear phase:

$$
u_{\text {sml,lin }}=\frac{k_{\text {lin }}}{(\mathrm{M} / \mathrm{H})}
$$

Table 3 reports for the various fuel packages tested the values of $u_{\text {smll,lin }}$ and the stack apparent density, $\mathrm{M} / \mathrm{V}$, where $\mathrm{V}$ is the stack volume. This ratio, linked to the porosity $\phi$ of the stack, is a characteristic of the paper type and it is linked not only to the properties of the single paper element but also to the collective behavior in piling (especially for foldable elements like newspaper sheets).

Concerning the data regarding the transient temperature profiles at different heights along the stack, it is interesting to observe a general trend: the thermal wave is always delayed in respect to the smoldering front as measured by the mass loss data. For instance, at a given position along the stack, the peak temperature is always achieved in a later time to that corresponding to the mass loss pertaining to that position. Hence it appears that the temperature peak in a specific location is registered when the smoldering front has already passed. As expected, this time delay increases as long as the smoldering proceeds downward along the stack, being maximum toward the bottom. The magnitude of this time delay varies with the fuel package, assuming the minimum value for the paper format having the highest smoldering velocity, ranging from $\approx 1 \mathrm{~h}$ for cardboard to $\approx 10 \mathrm{~h}$ for newspapers. Due to the complexity of the phenomenon, a detailed description of the transport mechanisms coupled with the reaction kinetics would be necessary to describe the thermal response of this configuration. In that respect, experimental studies like the once presented here, are a useful tool to get a comprehension of the physical aspects governing the smoldering (for instance the change in morphology) and get practical information on the time and temperature characteristics.

Focusing on the linear phase, an attempt to identify the relationship linking the measured $k_{\text {lin }}$ and $u_{\text {sml,lin }}$ to the physical variables governing the phenomenon has been attempted using multiple regression techniques. The data were subject to a linear multiple regression analysis using the least squares approach to identify the key variables and quantify the strength of their relationship with $k_{\text {lin }}$ and $u_{\text {sml,lin. }}$ The explanatory variables investigated covered both the single paper element (length L, width $\mathrm{W}$, grammage, aspect ratios like $\mathrm{W} / \mathrm{L}$ ) and the stack configuration (height $H$, perimeter $p$, cross section $A_{c}$, lateral area $A_{L}$, volume $V$, mass $\mathrm{M}$, porosity $\phi$, aspect ratios like $\mathrm{p} / \mathrm{A}_{\mathrm{C}}$ or $\mathrm{A}_{\mathrm{L}} / \mathrm{A}_{\mathrm{C}}$ ).

The analysis allowed us to identify the grammage and cross section for $k_{\text {lin }}$ and grammage and ratio $\mathrm{p} / \mathrm{A}_{\mathrm{C}}$ for $u_{\mathrm{sml}, \text { lin }}$ as the simpler and more efficient subset 
Table 3: Nominal downward smoldering velocity during the linear phase.

\begin{tabular}{|c|c|c|c|c|c|}
\hline $\begin{array}{l}\text { Test } \\
\text { no. }\end{array}$ & Paper sheet type & $\begin{array}{l}\text { Paper } \\
\text { initial } \\
\text { mass } \\
\mathrm{M} \\
\mathrm{(g}) \\
\end{array}$ & $\begin{array}{c}\text { Stack } \\
\text { apparent } \\
\text { density } \\
\mathrm{M} / \mathrm{V} \\
\left(\mathrm{g} / \mathrm{cm}^{3}\right) \\
\end{array}$ & $\begin{array}{c}\text { Constant mass } \\
\text { loss rate } \\
k_{\text {lin }} \\
(\mathrm{g} / \mathrm{min}) \\
\end{array}$ & $\begin{array}{l}\text { Nominal } \\
\text { smoldering } \\
\text { velocity } \\
u_{\mathrm{sml}, \mathrm{lin}} \\
(\mathrm{cm} / \mathrm{min}) \\
\end{array}$ \\
\hline 1 & $\begin{array}{l}\text { Glossy paper } \\
\text { LxW: } 50 \times 35 \mathrm{~cm} \\
\text { Gram.: } 200 \mathrm{~g} / \mathrm{m}^{2} \\
\mathrm{H}: 7 \mathrm{~cm}\end{array}$ & 9094 & 0.742 & 7.0223 & $5.4110^{-3}$ \\
\hline 2 & As test n. 1 & 9105 & 0.743 & 6.7579 & $5.2010^{-3}$ \\
\hline 3 & $\begin{array}{l}\text { As test } \mathrm{n} .1 \\
\text { but } \mathrm{H}=3.5 \mathrm{~cm}\end{array}$ & 4313 & 0.725 & 8.6308 & $6.8010^{-3}$ \\
\hline 4 & $\begin{array}{l}\text { Cardboard } \\
\text { LxW: } 42 \times 10.5 \mathrm{~cm} \\
\text { Gram.: } 200 \mathrm{~g} / \mathrm{m}^{2} \\
\text { H: } 10.5 \mathrm{~cm}\end{array}$ & 3836 & 0.828 & 4.6467 & $1.2710^{-2}$ \\
\hline 5 & $\begin{array}{l}\text { A3 paper } \\
\text { LxW: } 42 \times 29.7 \mathrm{~cm} \\
\text { Gram.: } 80 \mathrm{~g} / \mathrm{m}^{2} \\
\mathrm{H}: 9.8 \mathrm{~cm} \\
\end{array}$ & 9885 & 0.809 & 4.7166 & $4.6810^{-3}$ \\
\hline 6 & $\begin{array}{l}\text { Newspaper } \\
\text { LxW: } 35 \times 25 \mathrm{~cm} \\
\text { Gram.: } 40 \mathrm{~g} / \mathrm{m}^{2} \\
\text { H: } \sim 21 \mathrm{~cm} \\
\end{array}$ & 8097 & 0.441 & 2.9864 & $7.7510^{-3}$ \\
\hline 7 & $\begin{array}{l}\text { Newspaper } \\
2 \text { adjacent stacks } \\
\text { LxW: }(2 \times 22) \times 31 \mathrm{~cm} \\
\text { Gram.: } 40 \mathrm{~g} / \mathrm{m}^{2} \\
\text { H: } \sim 13.5 \mathrm{~cm} \\
\end{array}$ & 8145 & 0.442 & 2.0275 & $6.6010^{-3}$ \\
\hline 8 & $\begin{array}{l}\text { Newspaper } \\
\text { LxW: } 30 \times 20.5 \mathrm{~cm} \\
\text { Gram.: } 40 \mathrm{~g} / \mathrm{m}^{2} \\
\text { H: } \sim 16 \mathrm{~cm} \\
\end{array}$ & 4460 & 0.453 & 1.8385 & $5.8810^{-3}$ \\
\hline 9 & $\begin{array}{l}\text { Newspaper } \\
\text { LxW: } 40 \times 29 \mathrm{~cm} \\
\text { Gram.: } 40 \mathrm{~g} / \mathrm{m}^{2} \\
\text { H: } \sim 13 \mathrm{~cm} \\
\end{array}$ & 6906 & 0.458 & 3.1246 & $6.7210^{-3}$ \\
\hline
\end{tabular}

of explanatory variables. The results are reported in Tables 4 and 5. These variables allow easy predictions of the smoldering behavior of similar paper types. For instance the predicted value of $k_{\text {lin }}$ for a stack of A4 papers (grammage: $80 \mathrm{~g} / \mathrm{m}^{2}, \mathrm{~A}_{\mathrm{c}}: 623.7 \mathrm{~cm}^{2}$ ) is $2.84 \mathrm{~g} /$ min while the measured value is $3.66 \mathrm{~g} / \mathrm{min}[2]$.

\section{Conclusion}

The smoldering behavior of paper stacks ignited on top has been investigated. In the tests performed, smoldering after flaming has resulted to be a stable process that proceed with continuity, provided the ignition source is of sufficient strength. In all configurations tested, it has been observed a first phase of constant mass loss rate, followed by a decaying phase. A linear regression model 
has been derived that allowed to select grammage and paper size as the key variables. Further research is planned to cover other paper types and sizes and to establish an advanced model that could explain the results obtained.

Table 4: $\quad$ Multiple linear regression of the constant mass loss rate $k_{\text {lin. }}$.

\begin{tabular}{|c|c|c|c|c|c|c|}
\hline & \multicolumn{6}{|c|}{$k_{\text {lin }(\mathrm{g} / \mathrm{min})}=\beta_{\mathrm{Gr}}$ Grammage $_{(\mathrm{g} / \mathrm{m} 2)}+\beta_{\mathrm{Ac}} \mathrm{A}_{\mathrm{c}(\mathrm{cm} 2)}$} \\
\hline & \multicolumn{3}{|c|}{$\beta_{\mathrm{Gr}}$} & \multicolumn{3}{|c|}{$\beta_{\mathrm{Ac}}$} \\
\hline & Coefficient & $\begin{array}{l}\text { Standard } \\
\text { error }\end{array}$ & $t$ Stat & Coefficient & $\begin{array}{l}\text { Standar } \\
\text { d error }\end{array}$ & $t$ Stat \\
\hline $\begin{array}{l}\text { All data (9 tests): } \\
\text { glossy paper, } \\
\text { cardboard, A3 }\end{array}$ & 0.017967 & 0.00313 & 5.739 & 0.002246 & 0.000349 & 6.444 \\
\hline \multirow{2}{*}{$\begin{array}{l}\text { Regression } \\
\text { statistics }\end{array}$} & Multiple R & $\mathrm{R}^{2}$ & Adjusted $\mathrm{R}^{2}$ & $\begin{array}{l}\begin{array}{l}\text { Standard } \\
\text { error }\end{array} \\
\end{array}$ & & \\
\hline & 0.995 & 0.989 & 0.845 & 0.607 & & \\
\hline $\begin{array}{l}\text { Analysis of } \\
\text { variance }\end{array}$ & $\begin{array}{l}\text { Sum of } \\
\text { Squares }\end{array}$ & $\begin{array}{l}\text { Mean } \\
\text { Square } \\
\text { error }\end{array}$ & $\bar{F}$ & Significance $\mathrm{F}$ & & \\
\hline $\begin{array}{l}\text { Regression } \\
\text { Residual } \\
\text { Total }\end{array}$ & $\begin{array}{c}236.9 \\
2.6 \\
239.5\end{array}$ & $\begin{array}{l}118.5 \\
0.4\end{array}$ & 321 & $\begin{array}{l}p \text {-value }= \\
7.92 \mathrm{E}-07\end{array}$ & & \\
\hline
\end{tabular}

Table 5: $\quad$ Multiple linear regression of the smoldering velocity $u_{\text {sml,lin. }}$.

\begin{tabular}{|c|c|c|c|c|c|c|}
\hline & \multicolumn{6}{|c|}{$u_{\mathrm{sml}, \text { lin }(\mathrm{cm} / \mathrm{min})}=\beta_{\text {Gr }}^{\prime}$ Grammage $(\mathrm{g} / \mathrm{m} 2)+\beta^{\prime} \mathrm{p} / \mathrm{Ac} \mathrm{p} / \mathrm{Ac}_{\mathrm{c}(1 / \mathrm{cm})}$} \\
\hline & \multicolumn{3}{|c|}{$\beta_{\mathrm{Gr}}^{\prime}$} & \multicolumn{3}{|c|}{$\beta_{\mathrm{p} / \mathrm{Ac}}^{\prime}$} \\
\hline & Coefficient & $\begin{array}{l}\text { Standard } \\
\text { error }\end{array}$ & $t$ Stat & Coefficient & $\begin{array}{l}\text { Standard } \\
\text { error }\end{array}$ & $t$ Stat \\
\hline $\begin{array}{l}\text { All data (9 tests): } \\
\text { glossy paper, } \\
\text { cardboard, A3 }\end{array}$ & 7.804E-06 & $3.56 \mathrm{E}-06$ & 2.19 & $4.441 \mathrm{E}-02$ & $3.48 \mathrm{E}-03$ & 12.77 \\
\hline \multirow[t]{2}{*}{$\begin{array}{l}\text { Regression } \\
\text { statistics }\end{array}$} & Multiple R & $\mathrm{R}^{2}$ & Adjusted $\mathrm{R}^{2}$ & \begin{tabular}{|l}
$\begin{array}{l}\text { Standard } \\
\text { error }\end{array}$ \\
\end{tabular} & & \\
\hline & 0.994 & 0.987 & 0.843 & 0.001 & & \\
\hline $\begin{array}{l}\text { Analysis of } \\
\text { variance }\end{array}$ & $\begin{array}{l}\text { Sum of } \\
\text { Squares }\end{array}$ & $\begin{array}{l}\text { Mean } \\
\text { Square error }\end{array}$ & $\mathrm{F}$ & Significance F & & \\
\hline $\begin{array}{l}\text { Regression } \\
\text { Residual } \\
\text { Total }\end{array}$ & $\begin{array}{l}4.63 \mathrm{E}-04 \\
6.00 \mathrm{E}-06 \\
4.69 \mathrm{E}-04\end{array}$ & $\begin{array}{l}2.32 \mathrm{E}-04 \\
8.58 \mathrm{E}-07\end{array}$ & 270 & $\begin{array}{l}p \text {-value }= \\
1.32 \mathrm{E}-06\end{array}$ & & \\
\hline
\end{tabular}

\section{References}

[1] Ohlemiller, T. J., Smoldering Combustion (Section 2, Chapter 9). The SFPE Handbook of Fire Protection Engineering, NFPA, pp. 200-210, 1981.

[2] Tinaburri, A. \& F.A. Ponziani, Investigation on the flaming to smoldering transition in an arson fire, Proc. of the Int. Conf. on Fire and Materials, Interscience, pp. 743-757, 2013.

[3] Rein, G., Smouldering Combustion Phenomena in Science and Technology, International Review of Chemical Engineering, Vol. 1, pp. 3-18, 2009. 